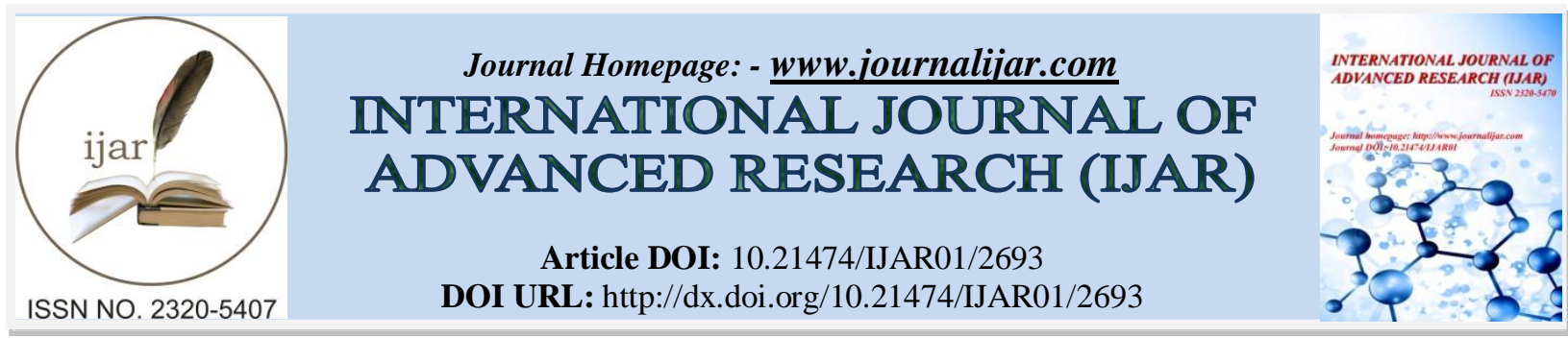

RESEARCH ARTICLE

\title{
COMPARISON OF LABORATORY METHODS FOR THE DIAGNOSTIC OF TRICHOMONASIS.
}

\author{
D. Oyungerel ${ }^{1}$, N. Giimaa ${ }^{1}$, E. Saruul ${ }^{1}$, M. Burnee ${ }^{1}$, T. Odgerel ${ }^{2}$, G. Nyamaa ${ }^{2}$, D. Narmandakh ${ }^{2}$, E. Tsatsral ${ }^{2}$, \\ A. Gurbadam ${ }^{1}$, Im Kyung il ${ }^{1}$ and D. Temuulen ${ }^{1}$. \\ 1. MNUMS department of Biology \&Histology. \\ 2. NCCD laboratory of bacteriology.
}

\section{Manuscript Info}

.1.........................

\section{Manuscript History}

Received: 31 October 2016

Final Accepted: 01 December 2016

Published: December 2016

Key words:-

Trichomonas vaginalis, trophozoite, PCR, method sensitivity

\section{Abstract}

In Mongolia, there is a variable number of Trichomonas vaginalis (T.vaginalis) infections reported and therefore we need a detection tool which is highly sensitive and specific. At the present study, we compared wet mount, gram stain, culture and PCR for detection of T.vaginalis from 109 samples collected in "UlaanTuuz" hospital in NCCID. As a result, $21.1 \%(23 / 109)$ were positive by wet mount, $18,3 \%(20 / 109)$ were positive by gram stain, $28.4 \%(31 / 109)$ were positive by culture and $36.6 \%(40 / 109)$ were positive by PCR respectively as compared to other methods. Further T.vaginalis trophozoite isolate was used to determine PCR sensitivity. Trophozoite isolate was counted by using haemocytometer and $10.1 \times 10^{4}$ was counted in one $\mathrm{mL}$ diluted swab sample. From that sample, trophozoite isolate was diluted 3156, 1578, 100, 50, 12, 3, 1.5 (1-2) per mL sample. PCR was performed serially diluted samples and as a result, all the samples had 102bp T.vaginalis specific DNA band and confirmed PCR method was sensitive. Out of 109 samples 17 (15.5\%) were positive by all detection methods. Since PCR had highest number of positivity, we have used it as a "golden standart" to calculate sensitivity and specificity of these methods. PCR had $100 \%$ specificity as compared to $98 \%$ wet mount, $98.5 \%$ gram stain and $100 \%$ culture. On the other hand culture had the highest sensitivity $77.5 \%$ as compared to PCR $100 \%$, wetmount and gram stain 47.5$77.5 \%$.

Copy Right, IJAR, 2016,. All rights reserved.

\section{Introduction:-}

Trichomonas vaginalis commonly causes vaginitis and perhaps cervicitis in women, as well as urethritis in both sexes, $10-50 \%$ of those cases are clinically asymptomatic. Иймээс энэхүҮ Үүсгэгчийг эрэгтэйчүүд эмэгтэйчүҮдэд зөөвөрлөдөг гэж үздэг. Worldwide, more than 180 million people get the infection with this parasite annually. Statistics from NCCID reports every 4-6 (48-63.6\% in 10000 population) people are infected with sexually transmitted diseases and T.vaginalis accounts $16.7-39.5 \%$ of those cases. Various methods have been used for the diagnosis of trichomoniasis such as wet mount, culture, Papanicolaou smear, and serologic test. Wet mount examination is an easy, simple, and rapid method but more than $10^{3} / \mathrm{ml}$ and live protozoa are required for detection. Culture demands a specialized medium and takes 2-5 days for the diagnosis. T.vaginalis is by indirect immunofluorescence test is the lack of sensitivity and specificity. In recent years, molecular biological techniques

Corresponding Author:- D. Oyungerel.

Address:- MNUMS department of Biology \&Histology. 
have a sexually transmitted infection disease. Therefore highly sensitive and specific clinical diagnostic methods needed for detection of T.vaginalis.

\section{Materials and Methods:- Patients and diagnostic test:-}

Total 109 female patients swab and vaginal secretions were employed in this study. All the patients had informed consent at "Ulaantuuz" voluntary clinic inNCCID hospital. All samples were tested the presence of T.vaginalisby wet smear, gram staining,culture by Feinberg-Whittington medium and PCR using TV-650 primer. Further T.vaginalis trophozoite isolate was used to determine PCR sensitivity. Trophozoite isolate was counted by using haemocytometer and $10.1 \times 10^{4}$ was counted in one $\mathrm{mL}$ diluted swab sample. From that sample, trophozoite isolate was diluted $3156,1578,100,50,12,3,1.5(1-2)$ per $\mathrm{mL}$ sample. PCR was performed serially diluted samples and as a result, all the samples had 102bp T.vaginalis specific DNA band and confirmed PCR method was sensitive. Sensitivity and specifity of clinical diagnostic methodwere determined by chi square test (SPSS-17).

\section{Result:-}

T.vaginalis was detected in culture, direct wet smear, Gram staining, and PCR techniques as follows, 28.4\% (31/109), $21.1 \%$ (23/109), 18,3\% (20/109) and 36.6\% (40/109), respectively. Total 15.5\% (17/109) samples were examined positive with T.vaginalis. PCR amplification method had highest sensitivity and specificity and therefore set as the "gold standard". In PCR,TV-650 primer set used which produces single band with 330bp length. The specificity of the direct wet smear was $79 \%$, gram staining was $76 \%$ and culture was $88 \%$ as compared to PCR amplification method. The sensitivity of the direct wet smear was 95\%, gram stain was $95 \%$ and culture was $100 \%$ and as compared to PCR amplification method. T.vaginalis isolate was prepared from culture positive samples where sub-cultured in Trypticase-yeast extract-maltose, Meingassner and Heyworth medium.T.vaginalistrophozoite in culture was counted and diluted to make 3156, 1578, 100,50,12,3, 1.5 cells per milliliter and DNA was extracted and subject to PCR amplification by TV-A5, TV-A6 primer sets (102 bp band). The highest dilution, 1.5 cells per milliliter Heyworth medium was positive by PCR. There was no correlation observed between clinical outcome and laboratory detection $(\mathrm{r}=0.001)$.

\section{Conclusions:-}

1. We diagnosedT.vaginalis new cases by different clinical laboratory methods, wet smear(21.1\%), and gram stain $(18.3 \%)$ and culture $(28.4 \%)$ and PCR, respectively.

2. Sensitivity of the PCR assay is $100 \%$ for detection of T.vaginalis and culture is $100 \%$ specific, $77,5 \%$ sensitive and kappa coefficient is much more significant. Sensitivity of Gram stain and wet mount are $47.5-55.0 \%$ and specificity is $98-98.5 \%$ and kappa coefficient is also significant.

\section{References:-}

1. Gary E Garber "The laboratory diagnosis of Trichomonas vaginalis" Can J Infect diseases Med Microbiology 2005;16(1):35-38

2. Gullermo Madico at all "Diagnosis of Trichomonas vaginalis infection by PCR using vaginal swab samples" Journal of clinical Microbiology, Nov.1998, p.3205-3210

3. Evangelia-Theophano Piperaki at all "Prevalence Trichomonas vaginalis infection in women attending a major gynaecological hospital in Greec" J Clin Pathol 2010;63:249-253

4. Jae-Sook Rey at all "Diagnosis Of Trichomoniasis by Polymerase Chain Reaction Reaction" Yonsei Medical Journal Vol 40, No.1, pp 56-60, 1999. 